\title{
Molecular Detection of Integrons, Colistin and $\beta$-lactamase Resistant Genes in Salmonella enterica Serovars Enteritidis and Typhimurium Isolated from Chickens and Rats Inhabiting Poultry Farms
}

\author{
Tsepo Ramatla ${ }^{1,2, *(\mathbb{D})}$, Kealeboga Mileng ${ }^{1}$, Rendani Ndou ${ }^{1}$, Nthabiseng Mphuti ${ }^{1}$, Michelo Syakalima ${ }^{1,3}$, \\ Kgaugelo E. Lekota ${ }^{2}$ and Oriel M.M. Thekisoe ${ }^{2}$ (D)
}

1 Department of Animal Health, School of Agriculture, North-West University, Private Bag X2046, Mmabatho 2735, South Africa; k.mileng@gmail.com (K.M.); Rendani.Ndou@nwu.ac.za (R.N.); nthabiseng.mphuthi@nwu.ac.za (N.M.); michsan65@gmail.com (M.S.)

2 Unit for Environmental Sciences and Management, North-West University, Private Bag X6001, Potchefstroom 2531, South Africa; Lekota.Lekota@nwu.ac.za (K.E.L.); thekisoe@gmail.com (O.M.M.T.)

3 Department of Disease Control, School of Veterinary Medicine, University of Zambia, Lusaka P.O. Box 32379, Zambia

* Correspondence: ra21205450@gmail.com; Tel.: +27-18-299-2521

check for updates

Citation: Ramatla, T.; Mileng, K.; Ndou, R.; Mphuti, N.; Syakalima, M.; Lekota, K.E.; Thekisoe, O.M. Molecular Detection of Integrons, Colistin and $\beta$-lactamase Resistant Genes in Salmonella enterica Serovars Enteritidis and Typhimurium Isolated from Chickens and Rats Inhabiting Poultry Farms. Microorganisms 2022, 10, 313. https: / /doi.org/10.3390/ microorganisms10020313 Academic Editor: Gabriela Jorge Da Silva

Received: 20 November 2021 Accepted: 13 January 2022 Published: 28 January 2022

Publisher's Note: MDPI stays neutral with regard to jurisdictional claims in published maps and institutional affiliations.

Copyright: (C) 2022 by the authors. Licensee MDPI, Basel, Switzerland. This article is an open access article distributed under the terms and conditions of the Creative Commons Attribution (CC BY) license (https:// creativecommons.org/licenses/by/ $4.0 /)$.

\begin{abstract}
The rapid growth of multidrug-resistant Salmonella is a global public health concern. The aim of this study was to detect integrons, colistin and $\beta$-lactamase resistance genes in Salmonella enteritidis and typhimurium. A total of 63 isolates of S. enteritidis $(n=18)$ and S. typhimurium $(n=45)$ from fecal samples of layers and rats at chicken farms were screened for antibiotic resistant genes. Conventional PCR was performed for the detection of integrons (classes 1, 2, and 3), colistin (mcr-1-5) and $\beta$-lactamase $\left(b l a_{C T X-M}, b l a_{C T X-M-1}, b l a_{C T X-M-2}, b l a_{C T X-M-9}, b l a_{C T X-M-15}, b l a_{T E M}, b l a_{S H V}\right.$, and bla $\left.a_{O X A}\right)$ resistant genes. Of these isolates, $77 \%$ and $27 \%$ of $S$. typhimurium and S. enteritidis harboured the $m c r-4$ encoded gene for colistin, respectively. The prevalence of class 1 integrons for S. typhimurium and S. enteritidis was $100 \%$ for each serovar, while for class 2 integrons of S. typhimurium and S. enteritidis it was $49 \%$ and $33 \%$ respectively, while class 3 integron genes was not detected. Our study also detected high levels of $\beta$-lactamase encoding genes (bla gene), namely bla $a_{C T X-M}, b l a_{C T X-M-1}, b l a_{C T X-M-9}$ and $b l a_{T E M}$ from both $S$. typhimurium and S. enteritidis. This, to our knowledge, is the first report of $m c r-4$ resistance gene detection in Salmonella serovars in South Africa. This study also highlights the importance of controlling rats at poultry farms in order to reduce the risk of transmission of antibiotic resistance to chickens and eventually to humans.
\end{abstract}

Keywords: integrons; colistin; $\beta$-lactamase; Salmonella serovars; antibiotic resistance

\section{Introduction}

Salmonella species are Gram-negative bacterial pathogens that are mostly associated with food poisoning outbreaks worldwide [1]. Salmonella serovars that cause human infection have been found to be more prevalent in chickens than in other animal types [2]. Contaminated poultry food products have been reported to be a source of more than 95\% of non-typhoidal Salmonella (NTS) infections [3,4]. Shonhiwa et al. [5] mentioned that outbreaks of food-borne diseases (FBDs) reported in South Africa between January 2013-December 2017 resulted in 11,155 individual infections, with 78\% hospital visits, $4 \%$ hospital admissions and $0.4 \%$ deaths. A majority of the outbreaks were recorded from KwaZulu-Natal (43\%), Gauteng (19\%), and Mpumalanga (12\%) provinces during the warmer months.

Antimicrobial resistance (AMR) is a growing global public health concern for humans and animals [6]. Several studies have revealed that antimicrobial use in food animals is a 
major contributor to the development of decreased susceptibility to antimicrobial agents in humans [7]. Microorganisms that are exposed to various antibiotics express resistance genes for protection and are capable of spreading their resistance genes to other non-pathogenic bacteria, thus creating resistance gene sources/reservoirs [8]. Antimicrobial resistance genes from food supplies have sparked increased interest in the public health sector [9].

Resistance to $\beta$-lactams, especially in Gram-negative bacteria, is primarily due to $\beta$ lactamase expression [10]. The $\beta$-lactams are widely used to treat infections in both animals and humans, especially infections which are due to Salmonella serovars [11]. Salmonella serovars are known to harbour the bla $a_{C T X-M}, b l a_{O X A}, b l a_{P E R}, b l a_{S H V}, b l a_{T E M}, b l a_{C T X}$, and $b l a_{C M Y}$ genes that encode extended spectrum beta-lactamases (ESBL) resistance [11,12]. A study conducted in Denmark revealed that, among $\beta$-lactamase resistance genes, $b l a_{T E M-1 b}$ was the mostly detected gene [13]. However, Salmonella strains have a lower prevalence of ESBLs than other Gram-negative bacteria [14].

Antibiotic resistance against colistin (COL), is becoming more common and a point of concern because it is a last-resort antibiotic used against difficult-to-treat pathogens such as Acinetobacter baumanni, Klebsiella pneumoniae, and Pseudomonas aeruginosa [15-20]. Although COL use in humans is uncommon in Africa, it is widely used in livestock [16,19]. COL is an over-the-counter drug supplied and dispensed by non-professionals in most African nations apart from South Africa [19]. In 2016, the first plasmid-mediated colistin resistance gene, $m c r-1$, was discovered in animals and humans [15]. Besides being detected in either animals or humans, the $m c r$ gene was originally discovered in seawater [21].

Integrons are defined by the presence of an integrase gene (IntI) [22]. They are genetic components that capture mobile gene cassettes that typically encode antimicrobial resistance determinants [23] and have been reported to contain one or more genes that code for antibiotic resistance [24]. The integrons are not considered as mobile genetic elements, although they can be transferred between bacteria by transposons or plasmids in which they are present $[22,25]$. About three types of integrons have been identified (IntI1, IntI2, and IntI3) [25]. The basic structure of integrons is composed of $5^{\prime}$ and $3^{\prime}$-conserved segments with gene cassettes containing antibiotic resistance genes [26]. They (IntI1, 2 and 3) have a primary recombination site (attI), a gene encoding an integrase belonging to the tyrosine-recombinase family (intI), and the $5^{\prime}$-conserved region contains a promoter $\left(\mathrm{Pc}_{\mathrm{c}}\right)$ (22). Most genes that are responsible for Salmonella resistance have been found in class 1 integrons [27]. By using site-specific recombination, Class I integrons can incorporate AMR genes from the environment [28] and have been reported in many Gram-negative bacteria [25]. The Class 2 integrons are embedded in the Tn7 family of transposons and were reported in Salmonella, Escherichia, Shigella species and other isolates [25].

Effective antimicrobial therapy is crucial in the treatment of protracted salmonellosis [29]. According to Du et al. [30], erythromycin and ciprofloxacin are the most commonly used antimicrobial agents in clinics. The rising prevalence of multidrug resistance (MDR) by Salmonella spp. to clinically significant antimicrobial drugs such as $\beta$-lactams is currently an emerging concern because MDR bacteria can infect humans through the food supply [30,31]. The fundamental issue with resistant bacteria is the scarcity of antibiotics available for their treatment [32].

The aim of this study was to determine the occurrence and spread of the integron types, colistin and $\beta$-lactamase resistance genes in Salmonella enterica serovars Typhimurium and Enteritidis isolates recovered from chickens (layers) and rats at chicken farms in North West province of South Africa.

\section{Materials and Methods}

\subsection{Salmonella serovars}

A total of 274 fecal samples were collected from chickens (layers) $(n=120)$ and rats $(n=154)$ in six commercial farms, as described in our previous study [8]. The capturing of rats and identification was described in our previous study, Ramatla et al. [33]. Salmonella species were isolated from the feces by following the International Organization for Stan- 
dardization method (ISO6579: 2002). Genomic DNA extraction using the Fungal/Bacterial Soil Microbe DNA Mini Prep kit, (Zymo Research, Irvine, CA, USA), PCR and sequencing were also carried out. All the sequenced isolates were deposited into the GenBank database and were assigned accession numbers. A total of 63 isolates of Salmonella enteritidis $(n=18)$ and typhimurium $(n=45)$ isolates were ultimately identified and used in this study.

\subsection{Antibiotic Susceptibility Testing}

The antibiotic resistance profile of the Salmonella serovars was determined using the Kirby-Bauer disc diffusion method on Mueller-Hinton agar [33]. The antibiotic panel consisted of 11 antibiotic discs (Davies Diagnostics, Johannesburg, South Africa) that included Sulphonamides $(300 \mu \mathrm{g})$, Streptomycin $(10 \mu \mathrm{g})$, Ampicillin $(10 \mu \mathrm{g})$, Enrofloxacin $(5 \mu \mathrm{g})$, Tetracycline $(30 \mu \mathrm{g})$, Gentamicin $(10 \mu \mathrm{g})$, Ciprofloxacin $(5 \mu \mathrm{g})$, Rifampicin $(\mu \mathrm{g})$, Chloramphenicol $(30 \mu \mathrm{g})$, Nalidixic acid $(30 \mu \mathrm{g})$ and Cephalothin $(30 \mu \mathrm{g})$. The E. coli ATCC 25922 and S. typhimurium ATCC 14028 were used as negative and positive controls respectively.

\subsection{Detection of Antibiotic Resistance Genes}

The isolates were screened for colistin genes (mcr-1, mcr-2, $m c r-3, m c r-4$ and $m c r-5)$ and $\beta$-lactamase (bla $a_{C T X-M}, b l a_{C T X-M-1}, b l a_{C T X-M-2}, b l a_{C T X-M-9}, b l a_{C T X-M-15}, b l a_{T E M}, b l a_{S H V}$, and $\left.b l a_{O X A}\right)$ resistance genes as well as different types of integrons (Class 1, 2 and 3). A molecular weight marker of 100 bp ladder (PROMEGA, Madison, WI, USA) was used to determine the size of the PCR amplicons.

\subsection{Analysis of Antimicrobial Resistance Genes}

\subsubsection{Detection of Colistin ( $\mathrm{mcr}$ )}

The fragments of the five mor genes were amplified using a multiplex PCR, and the PCR conditions are presented in Table 1 . The amplicon sizes of the mcr-1 to 5 ranged from 320 bp-1644 bp, respectively [34] (Table 1). Each PCR reaction was conducted in a total reaction volume of $25 \mu \mathrm{L}$ containing $12.5 \mu \mathrm{L}$ of the $2 X$ DreamTag Green Master Mix (0.4 mM dATP, $0.4 \mathrm{mM}$ dCTP $0.4 \mathrm{mM}$ dGTP and $0.4 \mathrm{mM}$ dTTP, $4 \mathrm{Mm} \mathrm{MgCl} 2$ and loading buffer), $8.5 \mu \mathrm{L}$ of nuclease-free water, $1 \mu \mathrm{L}$ of each oligonucleotide primer, and $1 \mu \mathrm{L}$ of DNA template. Amplified PCR products were electrophoresed on a 1.5\% (w/v) agarose gel stained with ethidium bromide and visualized under ultraviolet (UV) light.

\subsubsection{Detection of $\beta$-lactamase Genes}

All isolates were subjected to PCR amplification for detection of the $\beta$-lactamase resistance-encoding genes using primers listed in Table 1 . The following genes encoding the $\beta$-lactamase mechanism [35] were investigated: bla $a_{C T X-M}, b l a_{C T X-M-1}, b l a_{C T X-M-2}$, $b l a_{C T X-M-9}, b l a_{C T X-M-15}, b l a_{T E M}, b l a_{S H V}$, and $b l a_{O X A}$. The PCR reaction consisted of the $2 X$ DreamTaq Green Master Mix as mentioned above with PCR conditions shown in Table 1.

\subsubsection{Detection of Integrons (IntI) Genes}

The presence of Int (IntI1, IntI2, and IntI3) gene-encoding class 1 integrons was screened in all $S$. enteritidis, and $S$. typhimurium isolates using PCR. The primers listed in Table 1, were used to amplify the Int resistance genes [25,36,37]. The PCR reactions consisted of the 2X DreamTaq Green Master Mix as described above using PCR conditions as described in Table 1. 
Table 1. Antibiotic resistance genes, primers, and PCR conditions used in this study.

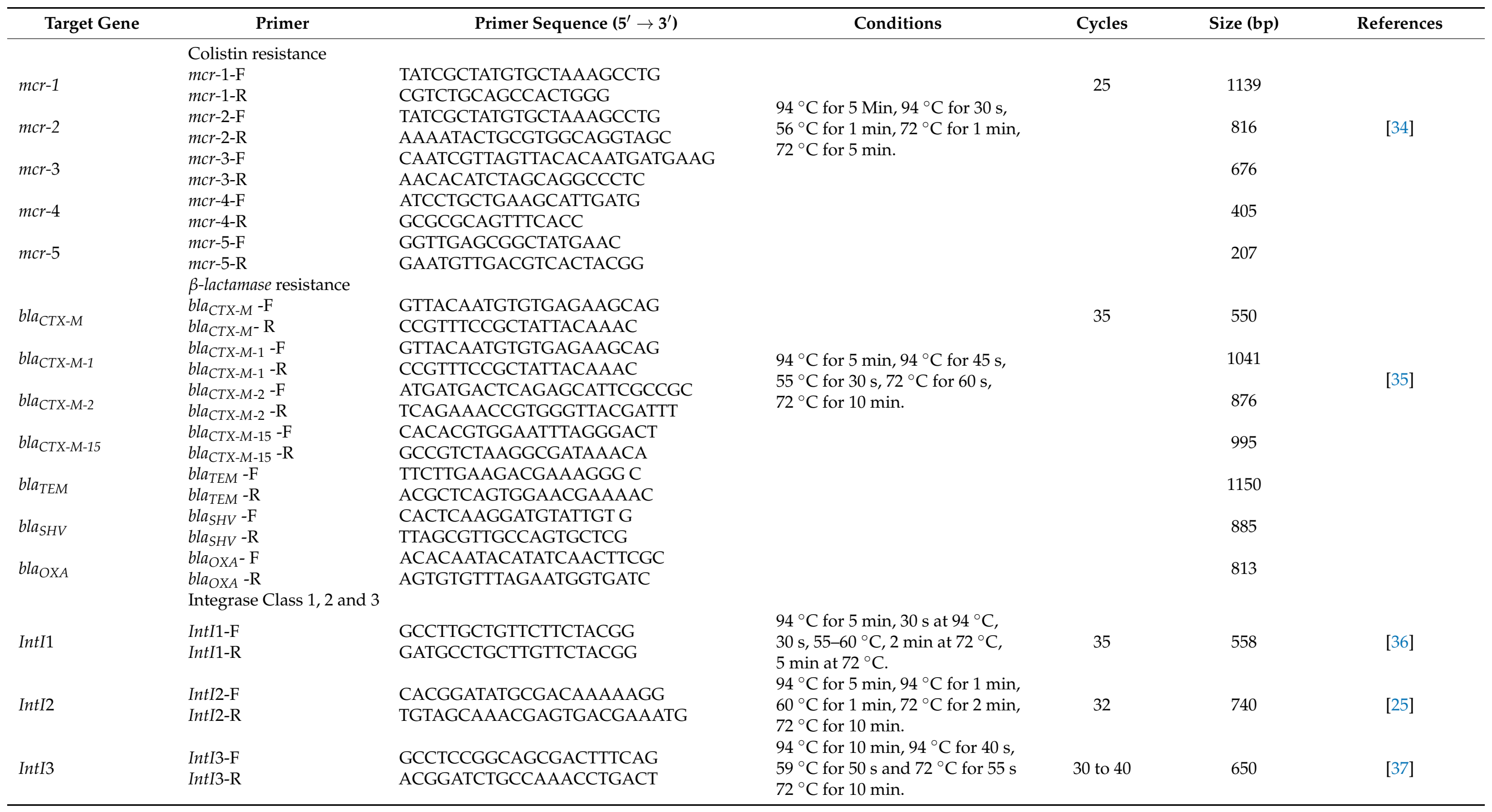




\section{Results}

\subsection{Antimicrobial Susceptibility Testing}

All 63 Salmonella enteritidis and typhimurium isolates used in this study were resistant against enrofloxacin 61.9\% (39/63), tetracycline 46.0\% (29/63), streptomycin 33.3\% $(21 / 63)$, cephalothin $22.2 \%$ (14/63), sulphonamide $20.6 \%(13 / 63)$, gentamicin $17.5 \%(11 / 63)$, nalidixic acid $14.3 \%(9 / 63)$, rifampicin $9.5 \%(6 / 63)$, ampicillin $4.8 \%(3 / 63)$ and ciprofloxacin $3.2 \%(2 / 63)$. None of the isolates were resistant to chloramphenicol (Table 2). Figure 1 shows isolates that were multidrug-resistant. About 21 isolates showed resistance to at least three classes of antibiotics, with five isolates showing resistance to up to six out of 11 tested antibiotics.

Table 2. Distribution of antimicrobial resistance from Salmonella enteritidis and typhimurium isolates.

\begin{tabular}{cccccc}
\hline & & & \multicolumn{3}{c}{ No. Resistant (\%) } \\
\hline Antibiotic & Code & Conc. $(\mu \mathrm{g})$ & S. typhimurium & S. enteritidis & Total \\
\hline Ampicillin & AMP & $10 \mu \mathrm{g}$ & $3(6.7 \%)$ & - & $3(4.8 \%)$ \\
Sulphonamides & SSS & $300 \mu \mathrm{g}$ & $8(17.8 \%)$ & $5(27.8 \%)$ & $13(20.6 \%)$ \\
Cephalothin & KF & $30 \mu \mathrm{g}$ & $11(24.4 \%)$ & $3(16.7 \%)$ & $14(22.2 \%)$ \\
Tetracycline & TE & $30 \mu \mathrm{g}$ & $23(51.1 \%)$ & $6(33.3 \%)$ & $29(46.0 \%)$ \\
Ciprofloxacin & NA & $30 \mu \mathrm{g}$ & - & $2(11.1 \%)$ & $2(3.2 \%)$ \\
Nalidixic acid & $\mathrm{C}$ & $30 \mu \mathrm{g}$ & $5(11.1 \%)$ & $4(22.2 \%)$ & $9(14.3 \%)$ \\
Chloramphenicol & CA & $10 \mu \mathrm{g}$ & - & - & - \\
Gentamicin & ENR & $5 \mu \mathrm{g}$ & $6(13.3 \%)$ & $5(27.8 \%)$ & $11(17.5 \%)$ \\
Enrofloxacin & RD & $5 \mu \mathrm{g}$ & $26(57.8 \%)$ & $13(72.2 \%)$ & $39(61.9 \%)$ \\
Rifampicin & $\mathrm{S}$ & $10 \mu \mathrm{g}$ & $6(13.3 \%)$ & - & $6(9.5 \%)$ \\
Streptomycin & CIP & $5 \mu \mathrm{g}$ & $14(31.1 \%)$ & $7(38.9 \%)$ & $21(33.3 \%)$ \\
\hline
\end{tabular}

$\mathrm{CA}=$ Gentamicin, $\mathrm{C}=$ Chloramphenicol, $\mathrm{CIP}=$ Ciprofloxacin, $\mathrm{RD}=$ Rifampicin, NA = Nalidixic acid, AMP = Ampicillin, ENR = Enrofloxacin, TE = Tetracycline, $\mathrm{KF}=$ Cephalothin and SSS $=$ Sulphonamide, $\mathrm{S}=$ Streptomycin

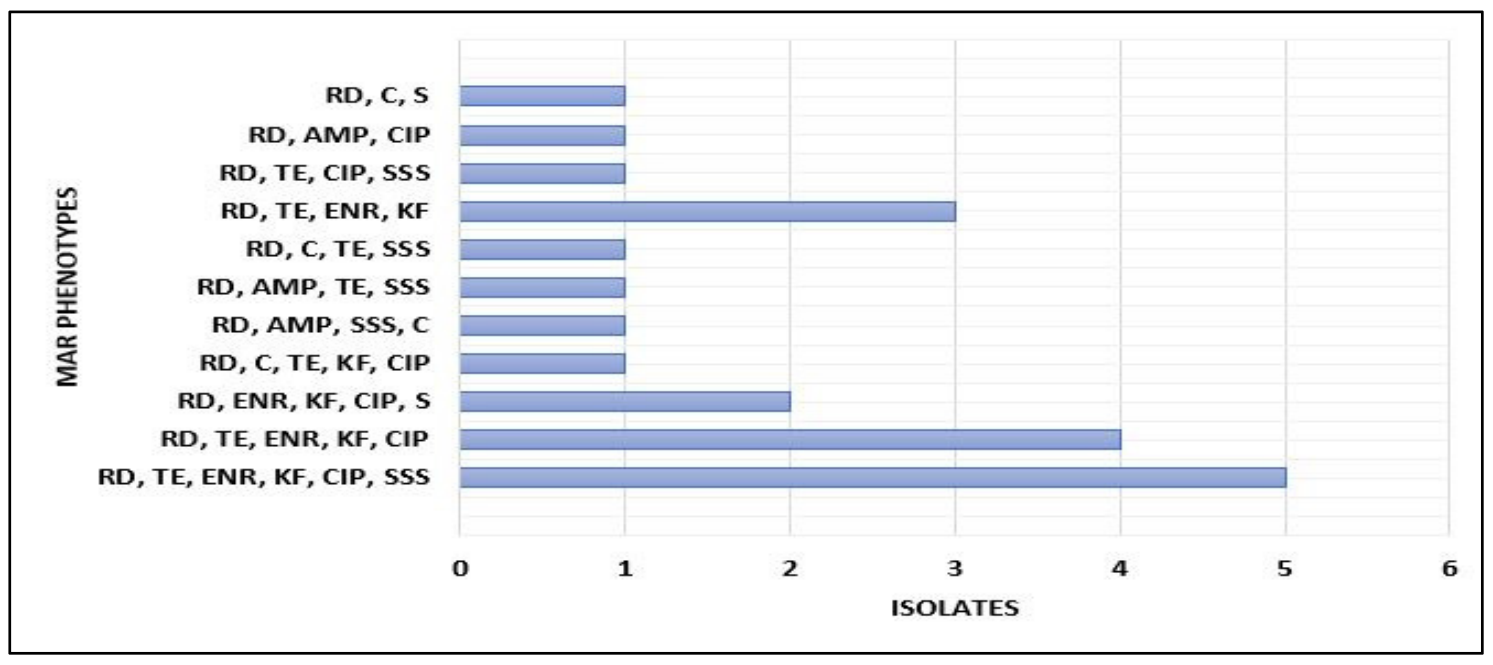

Figure 1. Multiple Antibiotic-Resistant Phenotypes pattern of S. enteritidis and typhimurium isolates. $\mathrm{CA}=$ Gentamicin, $\mathrm{C}=$ Chloramphenicol, $\mathrm{CIP}=$ Ciprofloxacin, $\mathrm{RD}=$ Rifampicin, $\mathrm{NA}=$ Nalidixic acid, $\mathrm{AMP}=$ Ampicillin, $\mathrm{ENR}=$ Enrofloxacin, $\mathrm{TE}=$ Tetracycline, $\mathrm{KF}=$ Cephalothin and SSS = Sulphonamide, $S=$ Streptomycin . 


\subsection{Detection of Antibiotic Resistance Genes}

The study revealed the presence of COL and $\beta$-lactamase antibiotic-resistant $S$. enteritidis and S. typhimurium isolates and as well as integrons. The gene encoding resistance to COL (mcr-4) was detected from 31 (49\%) Salmonella isolates in this study. About 58\% and $28 \%$ were detected from S. typhimurium and S. enteritidis isolates, respectively. Figures S1-S10 depict representative agarose gels containing PCR amplicons of the antibiotic resistance genes detected from this study.

In general, most of the isolates harboured $\beta$-lactamase encoding genes. A majority of S. typhimurium isolates consisted of ESBL encoding genes, including bla $a_{C T X-M-9,}, b l a_{C T X-M-2,}$ bla $_{C T X-M-15}, b l a_{T E M}, b l a_{S H V}$, and $b l a_{C T X-M}$ at $21(47 \%), 21(47 \%), 36(80 \%), 3(7 \%), 6(13 \%)$ and $10(22 \%)$, respectively. The summary of bla genes encoding $\beta$-lactam are shown in Figure 2. The bulk of $S$. enteritidis isolates carried bla $_{C T X-M}, b l a_{C T X-M-1}, b l a_{C T X-M-9}$, and $b l a_{T E M}$ genes at $n=7(39 \%), n=8(44 \%), n=6(33 \%)$, and $n=5(28 \%)$ respectively, all encoding for resistance to $\beta$-lactamase, as shown in Table 3.

Out of 63 isolates, only $84 \%$ were harbouring IntI1 gene encoding class 1 integrons, of which $78 \%$ and $100 \%$ were detected in S. typhimurium and S. enteritidis isolates respectively. IntI2 genes encoding class 2 integrons were detected in $22(49 \%)$ and $6(33 \%)$, S. typhimurium and S. enteritidis isolates, respectively (Table 3).

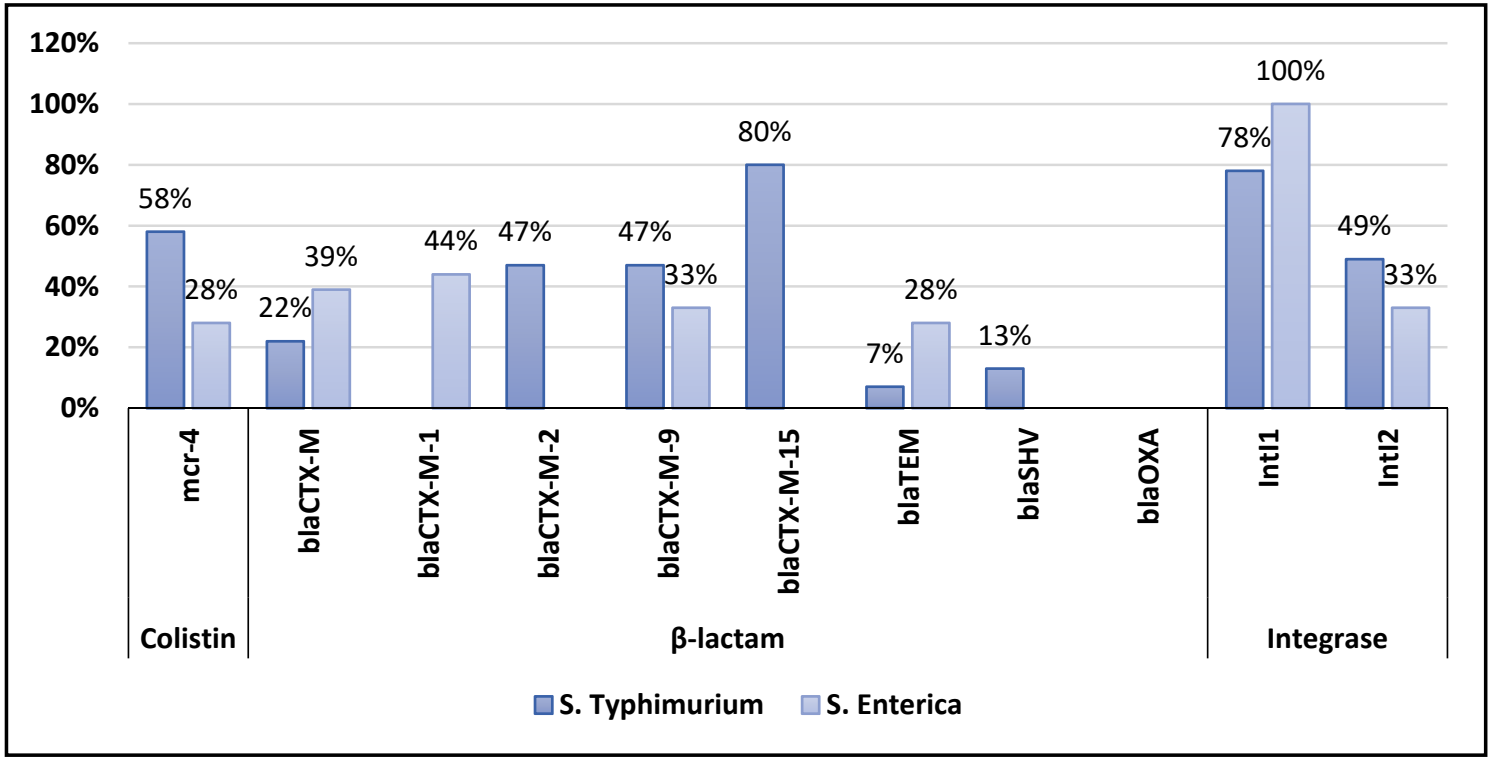

Figure 2. Distribution of antibiotic resistance genes among Salmonella enteritidis and typhimurium isolates. 
Table 3. Detection of different classes of antibiotic resistance genes and integrons from Salmonella enteritidis and typhimurium isolates.

\begin{tabular}{|c|c|c|c|c|c|c|}
\hline \multirow{2}{*}{ Serovars } & \multirow{2}{*}{ Sample ID } & \multirow{2}{*}{ Accession Number } & \multirow{2}{*}{ Antimicrobial-Resistant Genes Pattern } & \multicolumn{3}{|c|}{ Integrase } \\
\hline & & & & IntI1 & IntI2 & IntI3 \\
\hline \multirow[t]{33}{*}{ S. typhimurium } & R 1 & MH352147 & $m c r-4, b l a_{C T X-M-2}, b l a_{C T X-M-9}$ & + & - & - \\
\hline & R 3 & MH352149 & $m c r-4, b l a_{C T X-M}, b l a_{C T X-M-2}, b l a_{C T X-M-9}, b l a_{C T X-M-15}$ & + & + & - \\
\hline & $\mathrm{R} 6$ & MH352152 & $m c r-4, b l a_{C T X-M}, b l a_{C T X-M-2}, b l a_{C T X-M-9}$ & + & - & - \\
\hline & $\mathrm{R} 7$ & MH352153 & $m c r-4, b l a_{C T X-M-2}, b_{C} a_{C T X-M-9}$ & + & + & - \\
\hline & R 8 & MH352154 & $m c r-4, b l a_{C T X-M}, b l a_{C T X-M-2}, b l a_{C T X-M-9}$ & + & - & - \\
\hline & R 9 & MH352155 & 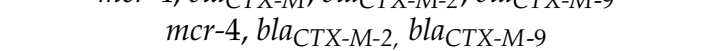 & + & - & - \\
\hline & R 10 & MH352156 & $m c r-4, b l a_{C T X-M-2}, b l a_{C T X-M-9,}, b_{T E M}$ & + & + & - \\
\hline & R 12 & MH352158 & $b l a_{C T X-M-2}, b l a_{C T X-M-9}$ & + & + & - \\
\hline & $\mathrm{R} 22$ & MH352168 & $m c r-4, b l a_{C T X-M}, b l a_{C T X-M-9}$ & + & + & - \\
\hline & R 25 & MH352171 & $m c r-4, b l a_{C T X-M-2}, b l a_{C T X-M-9}$ & + & + & - \\
\hline & R 28 & MH352174 & $m c r-4, b l a_{C T X-M-2}, b l a_{C T X-M-9}, b l a_{T E M}$ & + & + & - \\
\hline & R 29 & MH352175 & $m c r-4, b l a_{C T X-M-9}$ & + & + & - \\
\hline & R 30 & MH352176 & $m c r-4, b l a_{C T X-M-9}$ & + & + & - \\
\hline & R 36 & MH352182 & $m c r-4, b l a_{C T X-M}, b l a_{C T X-M-9}, b l a_{C T X-M-15}$ & + & + & - \\
\hline & R 37 & MH352183 & $m c r-4, b l a_{C T X-M-9}$ & + & - & - \\
\hline & R 39 & MH352185 & $m c r-4, b l a_{C T X-M-2}, b l a_{C T X-M-9}$ & + & - & - \\
\hline & $\mathrm{R} 44$ & MH352190 & $m c r-4, b l a_{C T X-M-9}$ & + & - & - \\
\hline & R 45 & MH352191 & $m c r-4, b l a_{C T X-M-9}$ & + & + & - \\
\hline & R 46 & MH352192 & $m c r-4, b l a_{C T X-M-9}$ & + & - & - \\
\hline & $\mathrm{R} 48$ & MH352194 & $b l a_{C T X-M-2}, b l a_{C T X-M-9}$ & + & - & - \\
\hline & R 49 & MH352195 & $b l a_{C T X-M-2}, b l a_{C T X-M-9}, b l a_{T E M}$ & + & + & - \\
\hline & R 51 & MH352197 & bla $a_{C T X-M-2}, b l a_{C T X-M-9}$ & + & - & - \\
\hline & R 52 & MH352198 & $b_{C T X-M-2}, b l a_{C T X-M-9}$ & + & - & - \\
\hline & R 53 & MH352199 & $m c r-4, b l a_{C T X-M}, b l a_{C T X-M-2}, b l a_{C T X-M-15}$ & + & + & - \\
\hline & R 54 & MH352200 & $m c r-4, b l a_{C T X-M-2}, b l a_{C T X-M-9}$ & + & - & - \\
\hline & R 56 & MH352202 & $b l a_{C T X-M-2}, b l a_{C T X-M-9}$ & + & - & - \\
\hline & $\mathrm{R} 60$ & MH352206 & $b l a_{C T X-M-9}$ & + & + & - \\
\hline & R 65 & MH352211 & $m c r-4, b l a_{C T X-M-9}$ & + & + & - \\
\hline & $\mathrm{R} 67$ & MH352213 & $m c r-4, b l a_{C T X-M-2}, b l a_{C T X-M-9}, b l a_{T E M}$ & + & - & - \\
\hline & C 6 & MH356675 & $m c r-4$ & - & - & - \\
\hline & C 7 & MH356676 & $m c r-4, b l a_{C T X-M}$ & + & + & - \\
\hline & C 11 & MH356680 & $m c r-4, b l a_{C T X-M}, b l a_{C T X-M-15}$ & - & - & - \\
\hline & C 12 & MH356681 & - & - & + & - \\
\hline
\end{tabular}


Table 3. Cont.

\begin{tabular}{|c|c|c|c|c|c|c|}
\hline \multirow{2}{*}{ Serovars } & \multirow{2}{*}{ Sample ID } & \multirow{2}{*}{ Accession Number } & \multirow{2}{*}{ Antimicrobial-Resistant Genes Pattern } & \multicolumn{3}{|c|}{ Integrase } \\
\hline & & & & IntI1 & IntI2 & IntI3 \\
\hline \multirow{31}{*}{ S. enteritidis } & C 23 & MH356692 & - & + & - & - \\
\hline & C 26 & MH356695 & $b l a_{C T X-M-15}$ & - & - & - \\
\hline & C 28 & MH356697 & $b l a_{C T X-M}, b l a_{C T X-M-15}$ & - & + & - \\
\hline & C 30 & MH356699 & bla $a_{C T X-M-15}$ & - & - & - \\
\hline & C 32 & MH356701 & - & - & - & - \\
\hline & C 34 & MH356703 & - & - & - & - \\
\hline & C 34 & MH356704 & - & - & - & - \\
\hline & C 37 & MH356706 & - & - & - & - \\
\hline & C 41 & MH356710 & $b l a_{C T X-M-15}$ & + & - & - \\
\hline & C 42 & МH356711 & - & - & - & - \\
\hline & C 43 & MH356712 & $b l a_{C T X-M}$ & - & - & - \\
\hline & C 44 & MH356713 & - & - & - & - \\
\hline & C 45 & МH356714 & - & + & + & - \\
\hline & C 46 & МH356715 & $b l a_{C T X-M-15}$ & - & - & - \\
\hline & C 1 & MH356670 & $b l a_{C T X-M-15}$ & + & - & - \\
\hline & C 8 & MH356677 & $m c r-4$ & + & - & - \\
\hline & C 22 & МH356691 & - & + & - & - \\
\hline & C 29 & MH356698 & $m c r-4$ & + & - & - \\
\hline & C 40 & МH356709 & $m c r-4, b l a_{C T X-M-1}$ & + & - & - \\
\hline & $\mathrm{R} 2$ & MH352148 & $m c r-4, b l a_{C T X-M-1}$ & + & - & - \\
\hline & R 4 & МH352150 & $b l a_{C T X-M-1}$ & + & - & - \\
\hline & R 7 & MH352153 & $b l a_{C T X-M-1}$ & + & + & - \\
\hline & R 27 & МH352173 & bla $_{C T X-M}$ & + & - & - \\
\hline & $\mathrm{R} 37$ & MH352183 & $b l a_{C T X-M}, b l a_{C T X-M-15}$ & + & - & - \\
\hline & R 50 & MH352196 & $b l a_{C T X-M}, b l a_{S H V}$ & + & + & - \\
\hline & R 57 & MH352203 & $m c r-4, b l a_{C T X-M}, b l a_{S H V}$ & + & + & - \\
\hline & R 58 & MH352204 & $b l a_{C T X-M}, b l a_{C T X-M-1}, b l a_{C T X-M-15}, b l a_{S H V}$ & + & - & - \\
\hline & R 59 & МH352205 & $b l a_{C T X-M}, b l a_{C T X-M-15}$ & + & - & - \\
\hline & R 62 & МH352208 & $b l a_{C T X-M}, b l a_{C T X-M-1}, b l a_{C T X-M-15}, b l a_{S H V}$ & + & - & - \\
\hline & R 64 & MH352210 & $b l a_{C T X-M-1}, b l a_{C T X-M-15}$ & + & + & - \\
\hline & R 68 & MH352214 & $b l a_{C T X-M}, b l a_{C T X-M-1}$ & + & + & - \\
\hline
\end{tabular}




\section{Discussion}

Antibiotic resistance in Salmonella species has now become a global public health concern. In this study, the disc diffusion test was used to determine the antibiotic-resistant profiles in Salmonella enterica serovars Enteriditis and Typhimurium. Our results demonstrated high phenotypic resistance for enrofloxacin (61.9\%), tetracycline (46.0\%), and streptomycin (33.3\%); however, a low antibiotic resistance was observed for ciprofloxacin (3.2\%). Some of antimicrobial agents such as streptomycin ampicillin, chloramphenicol, gentamycin, and cefotaxime are not commonly used in animal health and production in South Africa [38]. In the current study, 21 (33.3\%) of the isolates were multidrug-resistant. Our results are consistent with the findings of the previous studies conducted in Italy, Ghana and elsewhere in South Africa which reported multidrug resistance of $15 \%, 81.8 \%$ and $66.7 \%$ by Salmonella isolates, respectively [39-41].

The presence of integrons, colistin and $\beta$-lactamase resistant genes in Salmonella serovars continues to be a major food and public health burden worldwide, especially in poultry farming. Furthermore, detection of these resistant genes in rats around poultry houses highlights how they are maintained in the environment and the big task of controlling the scourge. This study detected different AMR genes present in Salmonella serovars isolated from chickens and rats collected from 2018 to 2019 in North West province poultry farms in South Africa.

The study detected numerous $\beta$-lactamase encoded genes $(b l a) ; b l a_{C T X-M}, b l a_{T E M}$, bla $_{C T X-M-1)}$ in S. enteritidis and S. typhimurium. However, only bla $a_{C T X-M-2}$ and bla $a_{C T X-M-15}$ genes were detected in S. typhimurium. These findings are in agreement with the observations in central Ethiopia by Eguale et al. [42], whereby $79 \%$ of $\beta$-lactamase genes $\left(b_{T E M}, b l a_{T E M-1}, b l a_{T E M-57}, b l a_{O X A-10}\right.$ and $\left.b l a_{C T X-M-15}\right)$ were detected in animal and human non-typhoidal Salmonella isolates. In another study conducted in Egypt, Salmonella isolates from chickens were also reported to be harbouring $\beta$-lactamase resistance genes [43]. However, a previous study in South Africa reported that Salmonella isolates haboured $b l a_{\mathrm{OXA}}, b l a_{\mathrm{CTX}-\mathrm{M}}$, and $b l a_{\mathrm{TEM}}$ from soil and water samples [44]. Our data has shown that $44 \%$ of $S$. enteritidis isolates from faecal samples of rats and chickens carried $b l a_{C T X-M-1}$ resistance genes. Various studies from other countries have also reported similar results where bla $_{C T X-M-1}$ was detected from $100 \%$ Salmonella isolates obtained from the Senegalese Reference Center for Enterobacteria during 2001-2002 in Senegal [45], from children in Mali [46], from poultry and humans in France and from poultry in Egypt [32]. In general, the current study detected high prevalence of ESBL encoding genes in Salmonella isolates. The significance of detecting $\beta$-lactamase resistance genes raises public health concerns by limiting the therapeutic choices for treating salmonellosis in animals and humans [47], and COL raises major health concerns, as it is used as a treatment of last resort $[18,19]$.

The prevalence of colistin resistance in South Africa from humans was quite low in 2012 (about 3\%), but it had climbed significantly to 13 percent by 2014 [48,49]. On April 2016, the South African Medicines Control Council (SAMC) hosted the first meeting of the Colistin Working Group in Pretoria which was aimed at learning more about COL resistance in the country, as well as the value of COL as an antibiotic in humans and animals, and to further start working on a "One Health" strategy [48]. The mcr-1 COL resistance gene was first reported from E. coli in the Gauteng and Western Cape provinces on samples from livestock and humans [32,50]. Our study has investigated the occurrence of COL resistant genes patterns in Salmonella spp., and it has been observed that about $58 \%$ and $28 \%$ of $S$. typhimurium and S. enteritidis isolates were harbouring the $m c r-4$ encoding gene for COL, respectively. A comparable result regarding the prevalence of the $\mathrm{mcr}-4$ gene was previously reported in S. typhimurium isolates in Italy from pigs [51]. The worrying observation of our study is that the detection frequency of $88 \%$ of $m c r-4$ in S. typhimurium was from faecal sample isolates of Rattus spp. This raises serious concern, as rodents easily adapt to any environment, including human surroundings, and can therefore maintain and distribute the resistance genes in an environment that is difficult to control. This is the first study to detect this gene ( $m c r-4)$ from Salmonella isolated from Rattus spp. and chickens 
in South Africa. Colistin and carbapenems are important antibiotics used to treat MDR bacterial infections in humans [52]. Therefore, the interactions between environment-ratpoultry including humans can encourage the spread of antibiotic-resistant bacteria and resistance genes $[53,54]$. Rats can get antibiotic resistant bacteria from chicken faeces, as a wide range of antimicrobials are used for chicken growth [55].

Another interesting finding was the presence of IntI1 and IntI2 encoding genes for integrons with $78 \%$ of S. typhimurium isolates harbouring Int I1, while $49 \%$ were carrying IntI2. On the other hand, all isolates of S. enteritidis were harbouring the IntI1 gene while only $33 \%$ of $S$. enteritidis isolates from rodents were carrying the IntI2 encoding gene. Our data revealed higher prevalence for detection of encoding genes for integrons as compared to a report from Portugal, whereby IntI2 was detected from only 3\% of S. typhimurium isolated from humans, food products, and the environment [56]. The existence of integrons and their flexible transmission have been shown to be ideal for the spread of drug-resistant genes and the acceleration of multidrug resistance [57]. In the matter of multidrug-resistant genes, integrons can encode genes related to the adaptation to different environments [58]. In addition, integrons contain genes that are frequently linked to multidrug resistance $[22,58,59]$.

\section{Conclusions}

The current study revealed a high prevalence of resistance to important antimicrobials such as enrofloxacin, tetracycline, streptomycin, cephalothin, sulphonamide, gentamicin, nalidixic acid, rifampicin, ampicillin and ciprofloxacin. Additionally, this study also found high prevalence of ESBLs in Salmonella isolates. The $\beta$-lactamase encoding genes bla $a_{C T X-M}$, $b a_{C T X-M-1}, b l a_{C T X-M-2}, b l a_{C T X-M-9}, b l a_{C T X-M-15}, b l a_{T E M}, b l a_{S H V}$, and $b l a_{O X A}$ were all detected from $S$. Enteritidis and Typhimurium. Furthermore, the majority of the isolates tested positive for class 1 and 2 integrons, indicating the presence of one or more antibiotic resistance genes. Lastly, the detection of the $m c r-4$ gene in Salmonella was a special finding and revealed the extent to which COL resistance is spreading in the country. These findings shed further light on the role of rats as carriers and potential distributors of genes conferring antimicrobial resistance in Salmonella from poultry facilities, which could ultimately be transmitted to humans through chicken products. Therefore, it is imperative to control rats at poultry farms in order to reduce the risk of transmission of antibiotic resistance to chickens, and eventually to humans. Future studies are also required to establish the sources of $m c r-4$ and to identify the bacteria that possess the $m c r-4$ gene in South Africa.

Supplementary Materials: The following are available online at https://www.mdpi.com/article/10 $.3390 /$ microorganisms10020313/s1, Figure S1: Representative agarose gel image of the bla $a_{C T X-M}$ gene products. Lane M: 100 bp DNA ladder; Lanes 2-11 positive gene fragments and Lane 1: negative control. Figure S2: Representative agarose gel image of the bla 100 bp DNA ladder; Lanes 2-11 positive gene fragments and Lane 1: negative control. Figure S3: Representative agarose gel image of the $b l a_{C T X-M-2}$ gene products. Lane M: $100 \mathrm{bp}$ DNA ladder; Lanes 1, 3-6, 9 positive gene fragments and Lane 11: negative control. Figure S4: Representative agarose gel image of the $b l a_{C T X-M-15}$ gene products. Lane M: $100 \mathrm{bp}$ DNA ladder; Lanes 2-17 positive gene fragments and Lane 1: negative control. Figure S5: Representative agarose gel image of the bla $a_{O X}$ gene products. Lane M: 100 bp DNA ladder; Lane 2 positive gene fragments and Lane 1: negative control. Figure S6: Representative agarose gel image of the $b l a_{T E M}$ gene products. Lane M: 100 bp DNA ladder; Lanes 2-11 positive gene fragments and Lane 1: negative control. Figure S7: Representative agarose gel image of the $b l_{S H V}$ gene products. Lane M: $100 \mathrm{bp}$ DNA ladder; Lanes 3-5, 8-11 positive gene fragments and Lane 1: negative control. Figure S8: Representative agarose gel image of the IntI1 gene products. Lane M: $100 \mathrm{bp}$ DNA ladder; Lanes 1-8 positive gene fragments and Lane 1: negative control. Figure S9: Representative agarose gel image of the IntI2 gene products. Lane M: 100 bp DNA ladder; Lanes 1-8 positive gene fragments and Lane 1: negative control. Figure S10: Representative agarose gel image of the $m c r-4$ gene products. Lane M: 100 bp DNA ladder; Lanes 1-8 positive gene fragments and Lane 1: negative control. 
Author Contributions: Conceptualization, T.R., M.S. and O.M.M.T.; Funding acquisition, N.M., R.N. and O.M.M.T.; Investigation, T.R. and K.M.; Methodology, T.R. and R.N.; Project administration, T.R. and N.M.; Validation, M.S., R.N. and O.M.M.T.; Writing-original draft, T.R.; Writing-review \& editing, K.M., K.E.L., M.S. and O.M.M.T. All authors have read and agreed to the published version of the manuscript.

Funding: The first author is a recipient of the North-West University Postdoctoral Scholarship. The study was supported by the National Research Foundation (NRF) incentive grant for rated researchers (GUN94187) made available to OMMT.

Institutional Review Board Statement: The study was approved based on Animal Research Ethics Committee (NWU-00274-18-A5) guidelines by North West University Research Ethics Regulatory Committee (NWU-RERC).

Informed Consent Statement: Not applicable.

Data Availability Statement: The data presented in this study are available on request from the corresponding author.

Acknowledgments: We are grateful to poultry farmers for their cooperation.

Conflicts of Interest: The authors declare that they have no conflict of interest.

\section{References}

1. Waldman, J.; Souza, M.N.; Fonseca, A.S.K.; Ikuta, N.; Lunge, V.R. Direct detection of Salmonella from poultry samples by DNA isothermal amplification. Br. Poult. Sci. 2020, 61, 653-659. [CrossRef]

2. Arkali, A.; Çetinkaya, B. Molecular identification and antibiotic resistance profiling of Salmonella species isolated from chickens in eastern Turkey. BMC Veter. Res. 2020, 16, 205. [CrossRef] [PubMed]

3. Motladiile, T.W.; Tumbo, J.M.; Malumba, A.; Adeoti, B.; Masekwane, N.J.; Mokate, O.M.; Sebekedi, O.C. Salmonella food-poisoning outbreak linked to the National School Nutrition Programme, North West province, South Africa. S. Afr. J. Infect. Dis. 2019, 34, 6. [CrossRef] [PubMed]

4. Keddy, K.H.; Takuva, S.; Musekiwa, A.; Puren, A.J.; Sooka, A.; Karstaedt, A.; Klugman, K.P.; Angulo, F.J. An association between decreasing incidence of invasive non-typhoidal salmonellosis and increased use of antiretroviral therapy, Gauteng Province, South Africa, 2003-2013. PLoS ONE 2017, 12, e0173091. [CrossRef]

5. Shonhiwa, A.; Ntshoe, G.; Essel, V.; Thomas, J.; McCarthy, K. A review of foodborne diseases outbreaks reported to the outbreak response unit, national institute for communicable diseases, South Africa, 2013-2017. Int. J. Infect. Dis. 2019, 79, 73. [CrossRef]

6. Esperón, F.; Sacristán, C.; Carballo, M.; de la Torre, A. Antimicrobial resistance genes in animal manure, manure-amended and nonanthropogenically impacted soils in Spain. Adv. Biosci. Biotechnol. 2018, 9, 469-480. [CrossRef]

7. Pérez-Moreno, M.O.; Picó-Plana, E.; de Toro, M.; Grande-Armas, J.; Quiles-Fortuny, V.; Pons, M.J.; Gomes, C.; Sáenz, Y.; Torres, C.; Ruiz, J. $\beta$-Lactamases, transferable quinolone resistance determinants, and class 1 integron-mediated antimicrobial resistance in human clinical Salmonella enterica isolates of non-Typhimurium serotypes. Int. J. Med. Microbiol. 2013, 303, 25-31. [CrossRef]

8. Ramatla, T.; Taioe, M.O.; Thekisoe, O.M.; Syakalima, M. Confirmation of Antimicrobial Resistance by Using Resistance Genes of Isolated Salmonella spp. in Chicken Houses of North West, South Africa. J. World's Poult. Res. 2019, 9, 158-165. [CrossRef]

9. Nghiem, M.N.; Nguyen, V.T.; Jeung, E.; Vo, T.T.B. Alternate antimicrobial resistance genes in multidrug resistant Salmonella spp. isolated from retail meats in Vietnam using RNA-sequencing analysis. J. Food Saf. 2019, 39, 12707. [CrossRef]

10. Miró, E.; Vergés, C.; García, I.; Mirelis, B.; Navarro, F.; Coll, P.; Prats, G.; Martínez-Martínez, L. Resistance to quinolones and beta-lactams in Salmonella enterica due to mutations in topoisomerase-encoding genes, altered cell permeability and expression of an active efflux system. Enferm. Infecc. Microbiol. Clin. 2004, 22, 204-211. [CrossRef]

11. Hasman, H.; Mevius, D.; Veldman, K.; Olesen, I.; Aarestrup, F. $\beta$-Lactamases among extended-spectrum $\beta$-lactamase (ESBL)resistant Salmonella from poultry, poultry products and human patients in The Netherlands. J. Antimicrob. Chemother. 2005, 56, 115-121. [CrossRef]

12. Tzouvelekis, L.; Tzelepi, E.; Tassios, P.T.; Legakis, N. CTX-M-type $\beta$-lactamases: An emerging group of extended-spectrum enzymes. Int. J. Antimicrob. Agents 2000, 14, 137-142. [CrossRef]

13. Olesen, I.; Hasman, H.; Møller Aarestrup, F. Prevalence of $\beta$-lactamases among ampicillin-resistant Escherichia coli and Salmonella isolated from food animals in Denmark. Microb. Drug Resist. 2004, 10, 334-340. [CrossRef]

14. Zhao, S.; Blickenstaff, K.; Glenn, A.; Ayers, S.L.; Friedman, S.L.; Abbott, J.W.; McDermott, P.F. $\beta$-Lactam Resistance in Salmonella Strains Isolated from Retail Meats in the United States by the National Antimicrobial Resistance Monitoring System between 2002 and 2006. Appl. Environ. Microbiol. 2009, 75, 7624-7630. [CrossRef]

15. Liu, Y.-Y.; Wang, Y.; Walsh, T.R.; Yi, L.-X.; Zhang, R.; Spencer, J.; Doi, Y.; Tian, G.; Dong, B.; Huang, X.; et al. Emergence of plasmid-mediated colistin resistance mechanism MCR-1 in animals and human beings in China: A microbiological and molecular biological study. Lancet Infect. Dis. 2016, 16, 161-168. [CrossRef] 
16. Maamar, E.; Alonso, C.A.; Hamzaoui, Z.; Dakhli, N.; Abbassi, M.S.; Ferjani, S.; Saidani, M.; Boubaker, I.B.-B.; Torres, C. Emergence of plasmid-mediated colistin-resistance in CMY-2-producing Escherichia coli of lineage ST2197 in a Tunisian poultry farm. Int. J. Food Microbiol. 2018, 269, 60-63. [CrossRef] [PubMed]

17. El Garch, F.; de Jong, A.; Bertrand, X.; Hocquet, D.; Sauget, M. mcr-1-like detection in commensal Escherichia coli and Salmonella spp. from food-producing animals at slaughter in Europe. Veter-Microbiol. 2018, 213, 42-46. [CrossRef] [PubMed]

18. Snyman, Y.; Whitelaw, A.C.; Barnes, J.M.; Maloba, M.R.B.; Newton-Foot, M. Characterisation of mobile colistin resistance genes (mcr-3 and mcr-5) in river and storm water in regions of the Western Cape of South Africa. Antimicrob. Resist. Infect. Control. 2021, 10, 96. [CrossRef] [PubMed]

19. Anyanwu, M.U.; Jaja, I.F.; Oguttu, J.W.; Jaja, C.J.; Chah, K.F.; Shoyinka, V.S. Is Africa ready for mobile colistin resistance threat? Infect. Ecol. Epidemiol. 2021, 11, 1962781. [CrossRef]

20. Kumar, H.; Chen, B.-H.; Kuca, K.; Nepovimova, E.; Kaushal, A.; Nagraik, R.; Bhatia, S.K.; Dhanjal, D.S.; Kumar, V.; Kumar, A.; et al. Understanding of Colistin Usage in Food Animals and Available Detection Techniques: A Review. Animals 2020, $10,1892$. [CrossRef] [PubMed]

21. Drali, R.; Berrazeg, M.; Zidouni, L.L.; Hamitouche, F.; Abbas, A.A.; Deriet, A.; Mouffok, F. Emergence of mcr-1 plasmid-mediated colistin-resistant Escherichia coli isolates from seawater. Sci. Total Environ. 2018, 642, 90-94. [CrossRef] [PubMed]

22. Deng, Y.; Bao, X.; Ji, L.; Chen, L.; Liu, J.; Miao, J.; Chen, D.; Bian, H.; Li, Y.; Yu, G. Resistance integrons: Class 1, 2 and 3 integrons. Ann. Clin. Microbiol. Antimicrob. 2015, 14, 45. [CrossRef]

23. Carattoli, A.; Tosini, F.; Giles, W.P.; Rupp, M.E.; Hinrichs, S.H.; Angulo, F.J.; Barrett, T.J.; Fey, P.D. Characterization of Plasmids Carrying CMY-2 from Expanded-Spectrum Cephalosporin-Resistant Salmonella Strains Isolated in the United States between 1996 and 1998. Antimicrob. Agents Chemother. 2002, 46, 1269-1272. [CrossRef] [PubMed]

24. Gillings, M.R. Integrons: Past, Present, and Future. Microbiol. Mol. Biol. Rev. 2014, 78, 257-277. [CrossRef] [PubMed]

25. Kargar, M.; Mohammadalipour, Z.; Doosti, A.; Lorzadeh, S.; Japoni-Nejad, A. High Prevalence of Class 1 to 3 Integrons among Multidrug-Resistant Diarrheagenic Escherichia coli in Southwest of Iran. Osong Public Health Res. Perspect. 2014, 5, 193-198. [CrossRef]

26. Goudarzi, M.; Azimi, H. Dissemination of Classes 1, 2, and 3 Integrons in Acinetobacter baumannii Strains Recovered from Intensive Care Units Using Polymerase Chain Reaction-Restriction Fragment Length Polymorphism. Jundishapur J. Microbiol. 2017, 10, 193-198. [CrossRef]

27. Faldynova, M.; Pravcova, M.; Sisak, F.; Havlickova, H.; Kolackova, I.; Cizek, A.; Karpiskova, R.; Rychlik, I. Evolution of Antibiotic Resistance in Salmonella enterica Serovar Typhimurium Strains Isolated in the Czech Republic between 1984 and 2002. Antimicrob. Agents Chemother. 2003, 47, 2002-2005. [CrossRef]

28. Rao, S.; Linke, L.; Doster, E.; Hyatt, D.; Burgess, B.A.; Magnuson, R.; Pabilonia, K.L.; Morley, P.S. Genomic diversity of class I integrons from antimicrobial resistant strains of Salmonella typhimurium isolated from livestock, poultry and humans. PLoS ONE 2020, 15, e0243477. [CrossRef]

29. Ehuwa, O.; Jaiswal, A.; Jaiswal, S. Salmonella, Food Safety and Food Handling Practices. Foods 2021, 10, 907. [CrossRef] [PubMed]

30. Du, Y.; Wang, C.; Ye, Y.; Liu, Y.; Wang, A.; Li, Y.; Zhou, X.; Pan, H.; Zhang, J.; Xu, X. Molecular Identification of Multidrug-Resistant Campylobacter Species from Diarrheal Patients and Poultry Meat in Shanghai, China. Front. Microbiol. 2018, 9, 1642. [CrossRef]

31. Zhao, X.; Hu, M.; Zhang, Q.; Zhao, C.; Zhang, Y.; Li, L.; Qi, J.; Luo, Y.; Zhou, D.; Liu, Y. Characterization of integrons and antimicrobial resistance in Salmonella from broilers in Shandong, China. Poult. Sci. 2020, 99, 7046-7054. [CrossRef]

32. Ahmed, A.M.; Shimamoto, T. Genetic analysis of multiple antimicrobial resistance in Salmonella isolated from diseased broilers in Egypt. Microbiol. Immunol. 2012, 56, 254-261. [CrossRef] [PubMed]

33. Ramatla, T.; Mphuthi, N.; Gofaone, K.; Taioe, M.O.; Thekisoe, O.M.M.; Syakalima, M. Identification of Rodent Species That Infest Poultry Houses in Mafikeng, North West Province, South Africa. Int. J. Zool. 2019, 2019, 1280578. [CrossRef]

34. Sekyere, J.O. Current State of Resistance to Antibiotics of Last-Resort in South Africa: A Review from a Public Health Perspective. Front. Public Health 2016, 4, 209. [CrossRef]

35. Rebelo, A.R.; Bortolaia, V.; Kjeldgaard, J.S.; Pedersen, S.K.; Leekitcharoenphon, P.; Hansen, I.M.; Guerra, B.; Malorny, B.; Borowiak, M.; Hammerl, J.A.; et al. Multiplex PCR for detection of plasmid-mediated colistin resistance determinants, mcr-1, mcr-2, mcr-3, mcr-4 and mcr-5 for surveillance purposes. Eurosurveillance 2018, 23, 17-00672. [CrossRef] [PubMed]

36. Firoozeh, F.; Zahraei-Salehi, T.; Shahcheraghi, F.; Karimi, V.; Aslani, M.M. Characterization of class I integrons among Salmonella enterica serovar Enteritidis isolated from humans and poultry. FEMS Immunol. Med. Microbiol. 2011, 64, 237-243. [CrossRef]

37. Mobaraki, S.; Aghazadeh, M.; Barhaghi, M.H.S.; Memar, M.Y.; Goli, H.R.; Gholizadeh, P.; Kafil, H.S. Prevalence of integrons 1, 2, 3 associated with antibiotic resistance in Pseudomonas aeruginosa isolates from Northwest of Iran. BioMedicine 2018, 8, 12-17. [CrossRef] [PubMed]

38. Jaja, I.F.; Bhembe, N.L.; Green, E.; Oguttu, J.; Muchenje, V. Molecular characterisation of antibiotic-resistant Salmonella enterica isolates recovered from meat in South Africa. Acta Trop. 2019, 190, 129-136. [CrossRef] [PubMed]

39. Gargano, V.; Sciortino, S.; Gambino, D.; Costa, A.; Agozzino, V.; Reale, S.; Alduina, R.; Vicari, D. Antibiotic Susceptibility Profile and Tetracycline Resistance Genes Detection in Salmonella spp. Strains Isolated from Animals and Food. Antibiotics 2021, 10, 809. [CrossRef] 
40. Aduah, M.; Adzitey, F.; Amoako, D.; Abia, A.; Ekli, R.; Teye, G.; Shariff, A.; Huda, N. Not All Street Food Is Bad: Low Prevalence of Antibiotic-Resistant Salmonella enterica in Ready-to-Eat (RTE) Meats in Ghana Is Associated with Good Vendors' Knowledge of Meat Safety. Foods 2021, 10, 1011. [CrossRef] [PubMed]

41. Mokgophi, T.; Gcebe, N.; Fasina, F.; Adesiyun, A. Antimicrobial Resistance Profiles of Salmonella Isolates on Chickens Processed and Retailed at Outlets of the Informal Market in Gauteng Province, South Africa. Pathogens 2021, 10, 273. [CrossRef] [PubMed]

42. Eguale, T.; Birungi, J.; Asrat, D.; Njahira, M.N.; Njuguna, J.; Gebreyes, W.A.; Gunn, J.S.; Djikeng, A.; Engidawork, E. Genetic markers associated with resistance to beta-lactam and quinolone antimicrobials in non-typhoidal Salmonella isolates from humans and animals in central Ethiopia. Antimicrob. Resist. Infect. Control. 2017, 6, 13. [CrossRef] [PubMed]

43. Sabry, M.A.; Abdel-Moein, K.A.; Abdel-Kader, F.; Hamza, E. Extended-spectrum $\beta$-lactamase-producing Salmonella serovars among healthy and diseased chickens and their public health implication. J. Glob. Antimicrob. Resist. 2020, 22, 742-748. [CrossRef] [PubMed]

44. Raseala, C.M.; Ekwanzala, M.D.; Momba, M.N.B. Shared Extended-Spectrum $\beta$-Lactamase-Producing Salmonella Serovars between Agricultural and Aquatic Environments Revealed through invA Amplicon Sequencing. Microorganisms 2020, 8, 1898. [CrossRef]

45. Sow, A.G.; Wane, A.A.; Diallo, M.H.; Boye, C.S.-B.; Aïdara-Kane, A. Genotypic characterization of antibiotic-resistant Salmonella enteritidis isolates in Dakar, Senegal. J. Infect. Dev. Ctries. 2007, 1, 284-288. [PubMed]

46. Boisramé, S.; Tandé, D.; Münck, M.-R.; Gouriou, S.; Nordmann, P.; Naas, T. Salmonella carriage in adopted children from Mali: 2001-08. J. Antimicrob. Chemother. 2011, 66, 2271-2276. [CrossRef]

47. Adesiji, Y.O.; Deekshit, V.K.; Karunasagar, I. Antimicrobial-resistant genes associated with Salmonella spp. isolated from human, poultry, and seafood sources. Food Sci. Nutr. 2014, 2, 436-442. [CrossRef]

48. Mendelson, M.; Brink, A.; Gouws, J.; Mbelle, N.; Naidoo, V.; Pople, T.; Schellack, N.; van Vuuren, M.; Rees, H.; Banoo, S.; et al. The One Health stewardship of colistin as an antibiotic of last resort for human health in South Africa. Lancet Infect. Dis. 2018, 18, e288-e294. [CrossRef]

49. National Institute for Communicable Diseases. Antimicrobial Resistance National Surveillance Maps for South Africa. Available online: http:/ / www.nicd.ac.za/index.php/httpscdwmicrostrategy-nhls-aczamicrostrategyaspmain-aspxservernhlssandmicsi0 3projectnhlsbiport0evt2048001srcmain-aspx-2048001documentid10c27d0e4b424b217efdc086730cd76dcurrentvie/ (accessed on 6 March 2018).

50. Coetzee, J.; Corcoran, C.; Prentice, E.; Moodley, M.; Mendelson, M.; Poirel, L.; Nordmann, P.; Brink, A.J. Emergence of plasmidmediated colistin resistance (MCR-1) among Escherichia coli isolated from South African patients. S. Afr. Med. J. 2016, 106, 449-450. [CrossRef]

51. Carattoli, A.; Villa, L.; Feudi, C.; Curcio, L.; Orsini, S.; Luppi, A.; Pezzotti, G.; Magistrali, C.F. Novel plasmid-mediated colistin resistance mcr-4 gene in Salmonella and Escherichia coli, Italy 2013, Spain and Belgium, 2015 to 2016. Eurosurveillance 2017, $22,30589$. [CrossRef]

52. Mthembu, T.; Zishiri, O.; El Zowalaty, M. Genomic Characterization of Antimicrobial Resistance in Food Chain and LivestockAssociated Salmonella Species. Animals 2021, 11, 872. [CrossRef] [PubMed]

53. Hassell, J.M.; Ward, M.J.; Muloi, D.; Bettridge, J.; Robinson, T.P.; Kariuki, S.; Ogendo, A.; Kiiru, J.; Imboma, T.; Kang'Ethe, E.K.; et al. Clinically relevant antimicrobial resistance at the wildlife-livestock-human interface in Nairobi: An epidemiological study. Lancet Planet. Health 2019, 3, e259-e269. [CrossRef]

54. Sonola, V.S.; Katakweba, A.S.; Misinzo, G.; Matee, M.I.N. Occurrence of Multi-Drug-Resistant Escherichia coli in Chickens, Humans, Rodents and Household Soil in Karatu, Northern Tanzania. Antibiotics 2021, 10, 1137. [CrossRef] [PubMed]

55. Agyare, C.; Boamah, V.E.; Zumbi, C.N.; Osei, F.B. Antibiotic Use in Poultry Production and Its Effects on Bacterial Resistance. In Antimicrobial Resistance-A Global Threat; Kumar, Y., Ed.; IntechOpen: London, UK, 2018; pp. 33-51.

56. Antunes, P.; Machado, J.; Peixe, L. Characterization of antimicrobial resistance and class 1 and 2 integrons in Salmonella enterica isolates from different sources in Portugal. J. Antimicrob. Chemother. 2006, 58, 297-304. [CrossRef]

57. Lu, Y.; Zhao, H.; Sun, J.; Liu, Y.; Zhou, X.; Beier, R.C.; Wu, G.; Hou, X. Characterization of Multidrug-Resistant Salmonella enterica Serovars Indiana and Enteritidis from Chickens in Eastern China. PLoS ONE 2014, 9, e96050. [CrossRef] [PubMed]

58. Corrêa, F.E.L.; Dantas, F.G.D.S.; Grisolia, A.B.; Crispim, B.D.A.; Oliveira, K.M.P. Identification of class 1 and 2 integrons from clinical and environmental Salmonella isolates. J. Infect. Dev. Ctries. 2014, 8, 1518-1524. [CrossRef] [PubMed]

59. Firoozeh, F.; Shahcheraghi, F.; Salehi, T.Z.; Karimi, V.; Aslani, M.M. Antimicrobial resistance profile and presence of class I integrongs among Salmonella enterica serovars isolated from human clinical specimens in Tehran, Iran. Iran. J. Microbiol. 2011, 3, 112-117. [PubMed] 